\title{
ResearchArticle
}

\section{Effect of seed priming on yield and yield components of soybean}

\author{
KUNAL V. JADHAV, N.V. KAYANDE, M.R. WANDHARE AND D.S. PHAD
}

\section{SUMMARY}

The results exhibited that seeds primed with $\mathrm{CaCl}_{2} @ 1 \%\left(\mathrm{~T}_{3}\right)$ and $\mathrm{GA}_{3} @ 500 \mathrm{ppm}\left(\mathrm{T}_{4}\right)$ recorded significantly higher germination percentage i.e. 84.67 per cent and 83.33 per cent, respectively over the untreated control $\mathrm{T}_{1}(76.00 \%)$. Treatment $\mathrm{T}_{3}$ recorded higher number of initial plant stand (117 plants), followed by treatment $\mathrm{T}_{4}$ (111 plants) and treatment $\mathrm{T}_{5}(111$ plants). This may likely contributed for boosting up economic yield in soybean cultivar, JS-335. The seed priming significantly influenced the seed yield and yield contributing characters of soybean. Highest value for seed yield per hectare was recorded by treatment $\mathrm{T}_{3} \mathrm{CaCl}_{2} @ 1 \%$ (20.12 qt/ha) followed by treatment $\mathrm{T}_{4}-\mathrm{GA}_{3} @ 50 \mathrm{ppm}(19.02 \mathrm{qt} / \mathrm{ha}), \mathrm{T}_{5}-$ $\mathrm{KNO}_{3} @ 1 \%$ (18.35 qt/ ha). All other treatments recorded higher yield than untreated control (14.05 qt/ha) showing to the corresponding favourable improvement in number of pods per plant, number of seeds per pod, test weight (g), seed yield per plot (g), seed yield per Ha (q).

Key Words : Seed priming, Yield, Components of soybean

How to cite this article : Jadhav, Kunal V., Kayande, N.V., Wandhare, M.R. and Phad, D.S. (2017). Effect of seed priming on yield and yield components of soybean. Internat. J. Plant Sci., 12 (1): 15-20, DOI: 10.15740/HAS/IJPS/12.1/15-20.

Article chronicle : Received : 07.07.2016; Revised : 07.11.2016; Accepted : 03.12.2016

\section{MEMBERS OF THE RESEARCH FORUM}

\section{Author to be contacted :}

N.V. KAYANDE, Department of Agriculture Botany, Dr. Panjabrao

Deshmukh Krishi Vidyapeeth, AKOLA (M.S.) INDIA

Email: navinchandra9981@gmail.com

Address of the Co-authors:

KUNAL V. JADHAV AND M.R. WANDHARE, Department of Agriculture Botany, Dr. Panjabrao Deshmukh Krishi Vidyapeeth, AKOLA (M.S.) INDIA

D.S. PHAD, College of Agriculture, Dr. Panjabrao Deshmukh Krishi Vidyapeeth, AKOLA (M.S.) INDIA 